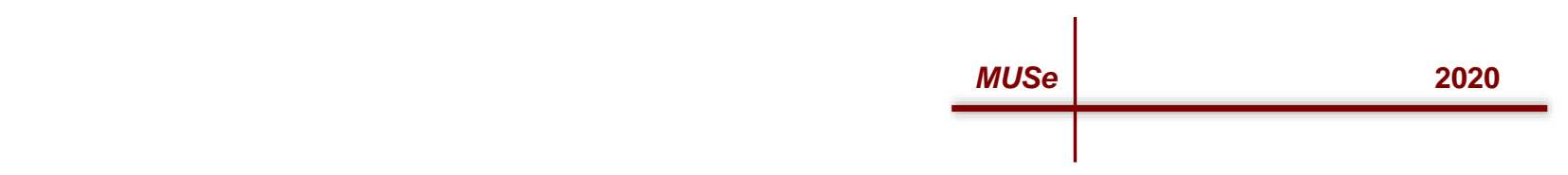

\title{
Student Engagement in MacEwan Career Development and Experiential Learning Services
}

\author{
Kyra Sklar, Amanda Julio, Sarah Ellis, \& Nicole Lakhram
}

\begin{abstract}
In working with MacEwan's Career Development and Experiential Learning (CDEL), the goal of our research was to discover their target market so that CDEL can efficiently and effectively promote their services. Having multiple differing variables amongst MacEwan students, our team analyzed which demographics will respond enthusiastically to marketing efforts. Our findings indicated that CDEL should focus their efforts on first to fourth year students mainly because the evidence found within our analysis shows no support to only target a specific year.

CDEL should develop their marketing strategies around students of all years of study equally. Creating "year of study workshops" may provide long-term interest for students. It is recommended that they run their online advertisements through Instagram, Linkedln, Blackboard, and Email primarily, as those are the most used and preferred means of gaining information by students. Creating relationships with students by their preferred means of communication will provide CDEL with the best response and engagement with the services.
\end{abstract}

\section{Problem Definition}

\section{A. Background of the Management and Marketing Research Problems}

Throughout our research, there were many changes in what we decided to ask ourselves about the problem we are facing: how to increase student engagement. Not only did we need to focus on how students will be affected by how we alter what CDEL does to increase interest, but also how the faculty of CDEL will need to change their organizational style. It is important to provide quality faculty-student engagement to help ensure students continue on their educational path and are successful in achieving their career goals (Masson et al., n.d.). The main foundation and core values of CDEL within the University are strongly built, however, unrecognized and underutilized. After being provided with secondary data from one of the CDEL representative's Gillian Kemp, it became apparent that their target market was not being reached. After reviewing CDEL's management strategies, we saw that the lack of resources and marketing presence on campus was contributing to the problem. In order to approach the management problem to increase student's awareness of Career Development and Experiential Learning, we defined several marketing research questions that would provide us with more information about the underlying causes of the problem:

- What number of students are aware and using the service?

Vol. 4(1) | DOI: https://doi.org/10.31542/muse.v4i1.1269

MacEwan University Student eJournal / @ 2020 under CC BY-NC | ISSN 2369-5617 
- What motivates students to use career services

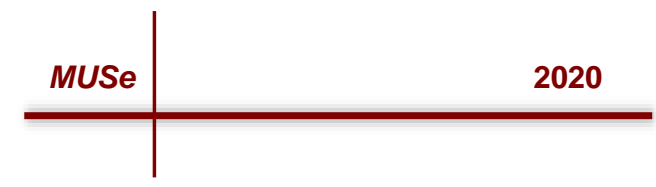

- What visual forms of communication will aid in the recognition of the services?

- Would students benefit from having mentors?

- What are the effective tools and methods for engaging students?

In our interview with Gillian Kemp, she voiced her concern with the accessibility of CDEL's service to students. Students must go see a different office to make an appointment, which can turn students off with having to go through so many steps. Also, the website "MacEwan Works" is not available on the student's portal or blackboard page. This website is a key tool to find job postings, and not many students are aware of it. We looked further into solving this research problem with our in-depth interviews which are described below.

\section{B. Tasks Developed to have a better Understanding of the Management and Marketing Research Problems}

As noted above, we gained information from an expert on CDEL, Gillian Kemp. She gave us lots of information about the service, and how they have conducted efforts to gain student traction. There is a lot of work that needs to go into showing a student whether a service is worth use or not. Students want simple and easy steps, which as of right now, CDEL does not completely provide. A review of our literature and exploratory research is described and analyzed below.

\section{Literature Review}

Universities, high schools, and other educational institutions study ways to increase facultystudent engagement in career and development services in order to maintain and advance their programs; these programs attract and retain students. Career Development and Experiential Learning provides students with the necessary resources to develop a strong career path. This is done through services such as advice and support in the career planning process, as well as sharing opportunities that connect classroom learning in the real world (Masson, et al., n.d.). Our management problem is how to gain student attraction and what we can recommend CDEL to do to make this to happen. The marketing research problem relates to how we took it upon ourselves to conduct in-depth interviews and send out an online survey to see how CDEL has been doing so far, and what they can start doing in the future.

\section{Qualitative and Exploratory Research}

The purpose of our literature review was to focus on specific topics on how we could further our knowledge on how to offer recommendations to CDEL. This was all meant to aid in our exploratory research so that we were well prepared to focus on what questions needed to be asked. We mainly focused on visual and personal engagement, online accessibility and resources, benefits of CDEL, and integration. Through the analysis and synthesis of scholarly articles based on these topics, we were then ready to construct an initial discussion guide for 


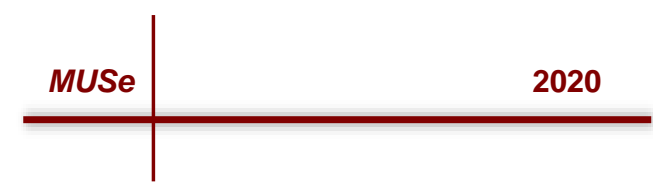

our in-depth interviews. While creating questions and seeing the results, we were able to come up with new questions for the next interviewee so that we could gain as much information as possible. The key topics we chose to focus on were whether the students were aware of the service, if they would see a need for it, and how CDEL could better reach out to them. We chose to only do in-depth interviews opposed to focus groups because we wanted an open conversation where no one felt as if they had to conform to what others were saying in a group setting. Through this, we were able to gain valuable insight from those students who had used the service, and whether they enjoyed the experience or not. We were also able to hear from students who haven't used CDEL and learn about why they have chosen not to inquire about it, and whether they were aware of the service or not. Students often are unsure of the skills they need in a professional environment or do not adequately "anticipate the professional skills and knowledge required for the future" (Fine, B A; Baker, D L; Fiddler, M B, 1996, p. 119). This is why we see it as important for students to take advantage of a free resource that will enable them to excel in their job search, and potentially begin an exciting career journey.

\section{Definition of management and marketing research problems.}

Our approach to solving the management problem of how CDEL can increase student engagement was through exploratory research of conducting in-depth interviews. These interviews were done with MacEwan students from various faculties, and we also sent out an online survey for students to complete. As market trends shift, CDEL must create new engagement activities that will interest the target market. By collecting data from our in-depth interviews and online surveys, we can offer viable recommendations on what the students want to see from CDEL. A basic solution to the marketing problem is making use of the online media students have access to. Through this, CDEL will be able to grab the attention of a variety of students and enable them to consider making use of their service. A deeper explanation of how they can do this will be provided in the recommendations section below.

\section{Analytical Framework of the Marketing Research Problem}

In order to properly define the analytical framework of our research problem, both conducting indepth interviews and analyzing and synthesizing scholarly articles was necessary. Our main problem focus was to address how to promote awareness of the services CDEL offers. Some of the common themes we identified while reviewing articles included personal and visual engagement strategies, importance of online accessibility, and resources and integrational benefits of CDEL. By researching these topics in our literature review, we were able to identify key variables to create particular questions for our in-depth interviews. The following analysis will discuss these different topics and further define the research problem regarding CDEL services. 


\section{Literature Review}

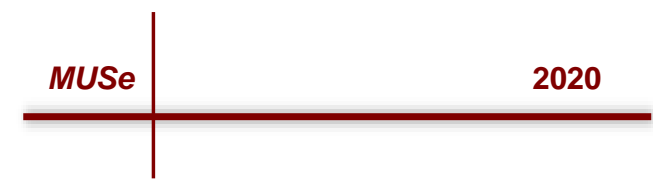

Our objective during the analysis and synthesis of scholarly articles was to identify how faculty and services can generate higher interaction and recognition from MacEwan University students. Through research of the themes mentioned, we were able to build a layout for in depth interviews by addressing key variables. After determining that our main focus was to engage a greater number of students, the secondary data analyzed by our group was in reference to mainly finding new, innovative techniques for online marketing strategies, as Zhang and Cabage (2017) argue, "With the internet growing each day, it increasingly becomes more difficult for certain websites/links to be recognized or found by students" ( $p 149)$. When we analyzed the raw data provided by career service counselor Gillian Kemp, it showed survey questions and the results from 45 participants. $60 \%$ of respondents don't know about MacEwanWorks, and 95\% say that having online career resources easily accessible to students would be beneficial. Additionally, $91 \%$ of respondents voted that CDEL is an essential service. Therefore, students must put effort into searching for CDEL's website, where there is information for students about the various benefits CDEL has to offer. Gaining a large number of students that participate in the services CDEL offers will start "providing students with opportunities to develop their cognitive, interpersonal, and intrapersonal capacities through a variety of experiences and interactions" (Zucca \& McFall, 2008. p.171). All of the studies we found led back to originally gaining a student's attention in finding a need for the resource, so that it can be exploited properly to benefit them in every way possible. This is why we centered our research around how we can use various marketing tools to get the word out.

\section{Qualitative Research}

To further our research, we developed in-depth interview questions for MacEwan students based on our literature review. The purpose of the questions was to gain insight on how CDEL can become more desirable to students, and how CDEL can better explore the target market. We chose to do in-depth interviews as opposed to focus groups, because we wanted to dig as deep as we could into each student's experience. We found it to be the best way for students to feel comfortable in describing why they have not used CDEL's services, whether it was because they saw no use for it, or that they were unaware it existed. We wanted an open conversation where no one felt as if they had to conform to what others were saying in a group setting. Students often are unsure of the skills they need in a professional environment or do not adequately "anticipate the professional skills and knowledge required for the future" (Fine, B A; Baker, D L; Fiddler, M B, 1996, p. 119).

Through the interview process, not only were we able to gain valuable insight into why students don't use the service, but we were also able to notify them of what the service has to offer. Students underestimate which skills are needed when entering the workforce, and CDEL can assist with fixing every minor, or major, skill a student may lack, such as a good resume, or interviewing techniques. We chose two students who have used the resource, and two who have not. Our objective was to uncover every detail that we could then use to start solving our marketing problem. In order to follow ethical procedures, our team adapted our research to 


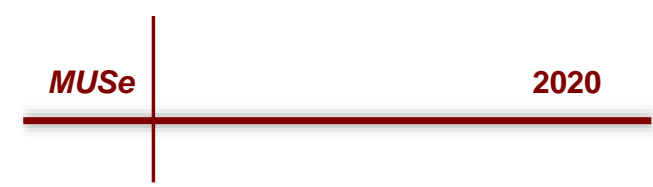

allow participants to sign a consent form regarding their involvement with our study. This was to ensure the protection of our participants and ethical value of our study. In the consent form, we stated we would not distribute their information to third parties.

After conducting our literature review and initial report findings, we then narrowed our research focus to developing a list of questions to draw correlations amongst our variables and the research question we were attempting to accomplish. Our main question was finding which variables caused students to utilize CDEL's services, and which variables affected why students utilized the services. From these findings, we were able to successfully concentrate our data collection results to formulate an ideal demographic.

\section{Research Questions and Hypothesis}

\section{Component 1}

Research question: Does a student's year of study affect if they have heard of MacEwan Career Development and Experiential Learning Service?

Hypothesis: Based on in-depth interviews conducted, we have concluded that students are most willing to use the services once they are closer to finishing their degree and graduating. Thus, when marketing to a particular demographic, we expect CDEL to focus their marketing efforts on third to fourth year students.

\section{Component 2}

Research question: What sources of social media would be most beneficial in reaching the target market?

Hypothesis: Through our initial research we hypothesized social media to be the preferred form of communication for information. We found this to be correct; therefore, increasing CDEL presence on social media would be favourable.

\section{Component 3}

Research question: Is there a correlation between the year students start looking for a job and if they have heard of MacEwan Experiential Learning Centre?

Hypothesis: It is common to assume university students are most inclined to start searching for a job closer to graduation; thus, the probability of a student searching for the services like CDEL at this time is relevant.

\section{Component 4}

Research question: What are the most favourable means of communication among MacEwan students?

Hypothesis: Through our qualitative research, it became clear that the preferred means of communication to students was through social media.

\section{Component 5}

Research question: What is the defining variable preventing MacEwan students utilizing CDEL? Hypothesis: When conducting in-depth interviews, we found that the main reason for students not utilizing the services available was due to the fact they had no knowledge of it at all. This 


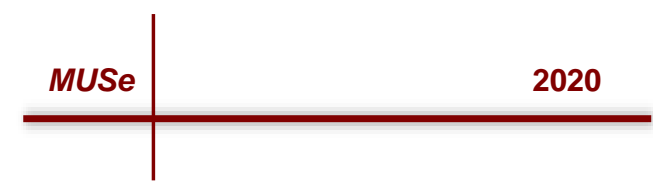

correlates heavily with CDEL marketing issue. Thus, it has become clear to our team that CDEL must market towards the most favourable form of communication.

\section{Research Design: Descriptive Design}

\section{a. Target Population, Sampling Frame}

In constructing our questionnaire, we wanted to appeal to our target population, respondents who are University students and who are part of the sampling unit of MacEwan University. The extent of our target population was MacEwan University, as our marketing research design was based upon the Career Development and Experiential learning services available to these students. Within this research design, the time under consideration was limited for we did not want to gather too much extraneous data, but quality data that was connected to our marketing research problem. For the representation of the elements of our target population, the sampling frame, group members were expected to reach out to fellow classmates and other students around campus. Multiple group members also reached out to professors and requested that the questionnaire be sent out to students in their classes.

The Sampling Method that was used in determining our sample size was probability sampling. Within the stratified probability sampling method, the elements in a group are homogeneous, for in our data collection this corresponds with the fact that our target population are all students. We opened our questionnaire to all of MacEwan's students and did not overlap this with all students in Edmonton.

\section{b. Fieldwork Data Collection}

The initial collection of our data was done through four in-depth interviews with a variety of individuals with different ages, years of study, and programs. The qualitative data that was received from these interviews was then used to formulate our questionnaire and distributed to the target population. Using google forms, our group was able to formulate 85 quality responses from MacEwan university students. Distribution of our questionnaire was done through social media platforms such as Facebook, email and personal interaction.

Table 1: Respondent Demographics

\begin{tabular}{|l|l|l|}
\hline Variable & Number of Respondents & $\%$ of Respondents \\
\hline Gender & & \\
Female & 56 & $65.9 \%$ \\
Male & 27 & $31.8 \%$ \\
Prefer Not to Say & 2 & $2.4 \%$ \\
\hline Year of Study & & \\
First Year & 12 & $14.3 \%$ \\
Second Year & 17 & $20.2 \%$ \\
\hline
\end{tabular}




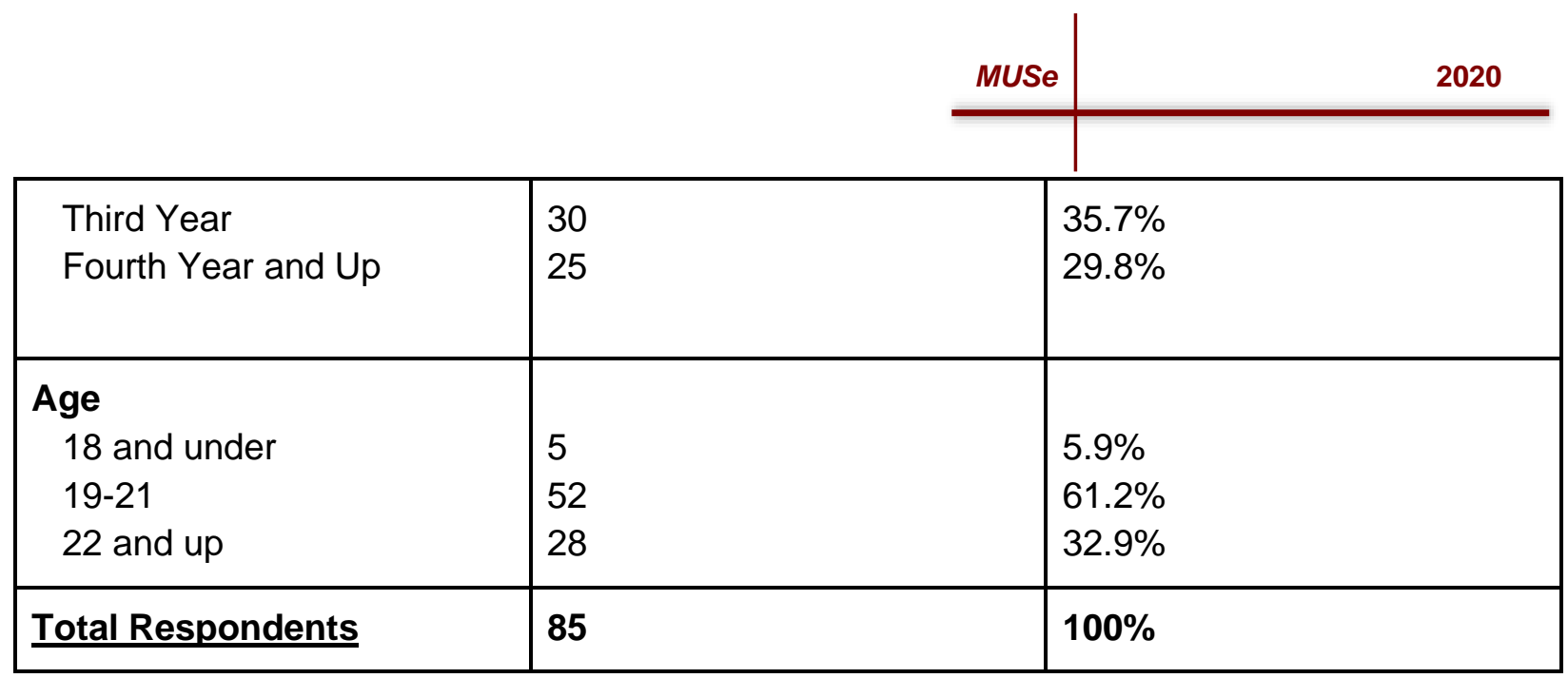

\section{c. Development, Pre-Test, and Execution of Questionnaires}

The questionnaire was developed based upon information and previously used survey questions the Career Development and Experiential learning had used, as well as information and data collected from our literature review and in-depth interviews. MacEwan professor Fernando Angulo reviewed the questionnaire and provided valuable insight and feedback before it was peer reviewed by our fellow classmates. During the exchange of questionnaires throughout our class, peer feedback was critical in determining how our questionnaire would be perceived by our target population. Through the development, pre-test, and execution of our questionnaire, adjustments and any necessary changes were orchestrated in order to ensure our questions were easily understood by the general public.

\section{Ethical Issues}

The responses that were gathered within our data collection were based upon the trust and security of researchers and respondents. Based upon the information and data that was collected, our trust was in the respondents to complete the questionnaire with $100 \%$ accuracy. There are certain variables that we are unable to control, such as personal conflict as well as data that may not have been $100 \%$ accurate. In conducting any survey, this can be noted as a limitation. Our group made a conscious, ethical effort to make sure that this was free from our respondents' answers for if this was to occur, it could falsify our information, and ruin our data collected. Certain ethical issues like these could be avoided through in-person surveys, however with a limited time frame, this method was not an option to our group. We are confident that the 85 responses we received from our questionnaire contain quality data that we were able to draw correlations from.

\section{Data Analysis and Results}

\section{Plan of Data}

In order to analyze our research questions, we conducted cross-tabulations, ANOVA tests and bivariate correlation tests. Through our statistical analysis we found which variables had the highest level of significance, and therefore which were the most important variables for our 


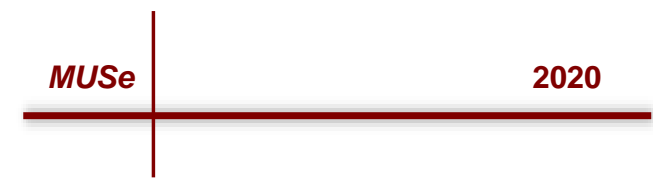

research. We chose to use the ANOVA test in order to find the relationship between an individual's social media platform use and whether or not they have heard of CDEL. ANOVA allowed us to compare one variable over a range of categories in a relatively easy manner to understand. Additionally, we used cross tabulations much to the same effect when comparing a respondent's year of study when they search for a job and if they have heard of MacEwan CDEL, amongst a few other cross tabulations. Through these tests, we hoped to gain adequate knowledge of the factors affecting CDEL and how to cater the services to meet the requirements of the target market at hand.

\section{Findings}

Research question \#4: What are the most favourable means of communication among MacEwan students?

All together there are 173 responses. Students answered that they are most interested in receiving information through Blackboard, which accounts for 52 responses $(30.1 \%)$, and the second highest being through email, accounting for 49 responses $(28.3 \%)$. If we look at it in terms of percent of cases, we see that $66.6 \%$ are in favour of Blackboard, and $62.8 \%$ are in favour of emails. So about $129.4 \%$ are in favour of medias that are provided by MacEwan. We chose not include posters in our frequency table because of how low the number of students is who prefer to hear from CDEL through poster usage.

Table 2: Preferred Means of Communication

\section{\$Pref_Means Frequencies}

\begin{tabular}{ll|r|r|r} 
& & \multicolumn{2}{c|}{ Responses } & \multicolumn{2}{c}{ Percent of } \\
& N & Percent & Cases \\
\hline $\begin{array}{l}\text { Preferred Means of } \\
\text { Communication }^{\mathrm{a}}\end{array}$ & Blackboard & 52 & $30.1 \%$ & $66.6 \%$ \\
\cline { 2 - 5 } & E-mail & 49 & $28.3 \%$ & $62.8 \%$ \\
\hline & In-Class Visits & 8 & $4.6 \%$ & $10.3 \%$ \\
\hline & Myportal & 39 & $22.5 \%$ & $50.0 \%$ \\
\hline Social Media & 25 & $14.5 \%$ & $32.1 \%$ \\
\hline & & & & \\
\hline Total & 173 & $100.0 \%$ & $221.8 \%$ \\
\hline
\end{tabular}




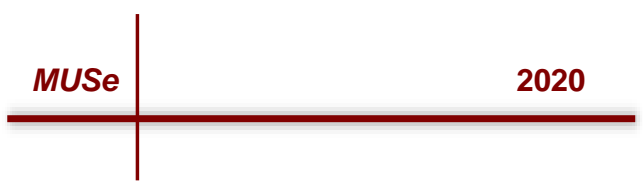

Graph 1: Simple Bar Count of Preferred Means of Communication

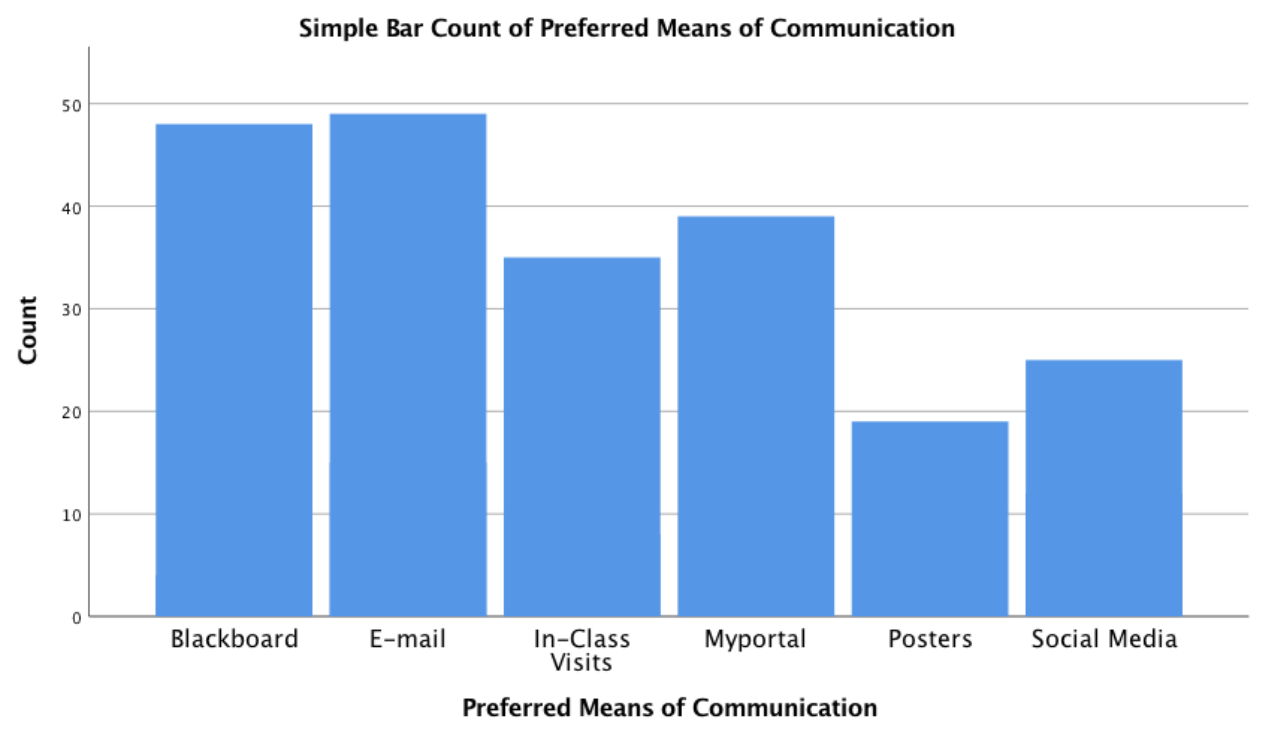

The visual representation shows the count number of responses to those who prefer a certain means of communication to hear about CDEL. As described above through the multiple response analysis frequency table, E-mail has 49 responses, while Blackboard has 48 responses in favour of hearing about CDEL through that form of media.

\section{Bivariate Analysis of Key Variables}

Question 1: Does a students' year of study affect if they heard of MacEwan Career Development and Experiential Learning Service?

For the first question, we used a crosstabulation to view the relationship between the year of study students are in, along with if the students have heard of CDEL. Although these two variables present have a high $\mathrm{p}$-value, causing our results to reject the hypothesis that the variables are related, we believe these results would be significantly different if we were able to gather a higher amount of respondents. However, a higher $p$-value within this correlation identifies that CDEL needs to target students from all years, as there is no evidence to support targeting students in third or higher years of study. 


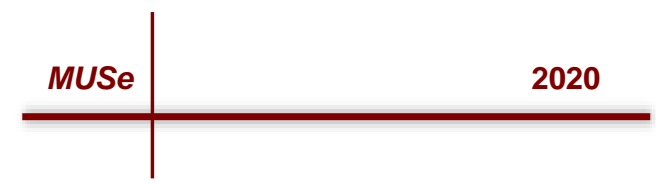

Table 3: Year of Student's Study Correlation with Heard of MacEwan Career Development and Experiential Learning

\begin{tabular}{|c|c|c|c|c|c|}
\hline & & & \multicolumn{2}{|c|}{$\begin{array}{l}\text { Have you Heard of } \\
\text { MacEwan CDEL? }\end{array}$} & \multirow[b]{2}{*}{ Total } \\
\hline & & & No & Yes & \\
\hline \multirow{10}{*}{$\begin{array}{l}\text { Year } \\
\text { of } \\
\text { Study }\end{array}$} & \multirow{5}{*}{$\begin{array}{l}\text { First \& Second } \\
\text { Year }\end{array}$} & Count & 16 & 13 & 29 \\
\hline & & Expected Count & 14.8 & 14.2 & 29.0 \\
\hline & & $\begin{array}{l}\% \text { within Year of } \\
\text { Study }\end{array}$ & $55.2 \%$ & $44.8 \%$ & $100.0 \%$ \\
\hline & & $\begin{array}{l}\% \text { within Have you } \\
\text { heard of CDEL? }\end{array}$ & $37.2 \%$ & $31.7 \%$ & $34.5 \%$ \\
\hline & & $\%$ of Total & $19.0 \%$ & $15.5 \%$ & $34.5 \%$ \\
\hline & \multirow[t]{5}{*}{ 3rd Year and Up } & Count & 27 & 28 & 55 \\
\hline & & Expected Count & 28.2 & 26.8 & 55.0 \\
\hline & & $\begin{array}{l}\% \text { within Year of } \\
\text { Study }\end{array}$ & $49.1 \%$ & $50.9 \%$ & $100.0 \%$ \\
\hline & & $\begin{array}{l}\% \text { within Have you } \\
\text { heard of CDEL? }\end{array}$ & $62.8 \%$ & $68.3 \%$ & $65.5 \%$ \\
\hline & & $\%$ of Total & $32.1 \%$ & $33.3 \%$ & $65.5 \%$ \\
\hline \multirow[t]{4}{*}{ Total } & & Count & 43 & 41 & 84 \\
\hline & & Expected Count & 43.0 & 41.0 & 84.0 \\
\hline & & $\begin{array}{l}\% \text { within Year of } \\
\text { Study }\end{array}$ & $51.2 \%$ & $48.8 \%$ & $100.0 \%$ \\
\hline & & $\begin{array}{l}\% \text { within Have you } \\
\text { heard of CDEL? }\end{array}$ & $100.0 \%$ & $100.0 \%$ & $100.0 \%$ \\
\hline
\end{tabular}


$100.0 \%$

Table 3b: Chi Square Test: Year of Study correlated with the Respondent's Knowledge of CDEL Chi-Square Tests

\begin{tabular}{|c|c|c|c|c|c|}
\hline & Value & $\mathrm{df}$ & $\begin{array}{l}\text { Asymptotic } \\
\text { Significance } \\
\text { (2-sided) }\end{array}$ & $\begin{array}{l}\text { Exact Sig. (2- } \\
\text { sided) }\end{array}$ & $\begin{array}{l}\text { Exact Sig. (1- } \\
\text { sided) }\end{array}$ \\
\hline Pearson Chi-Square & $.281^{a}$ & 1 & .596 & & \\
\hline Likelihood Ratio & .281 & 1 & .596 & & \\
\hline Fisher's Exact Test & & & & .651 & .382 \\
\hline $\begin{array}{l}\text { Linear-by-Linear } \\
\text { Association }\end{array}$ & .278 & 1 & .598 & & \\
\hline $\mathrm{N}$ of Valid Cases & 84 & & & & \\
\hline
\end{tabular}

a. 0 cells $(0.0 \%)$ have expected count less than 5 . The minimum expected count is 14.15 .

b. Computed only for a $2 \times 2$ table

$\mathrm{P}$ value is 0.596 , with and alpha of 0.05 , reject $\mathrm{Ho}$ and accept $\mathrm{Ha}$. 


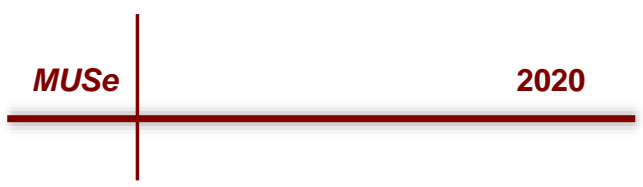

Graph 2: Year of Study * Have you Heard of CDEL

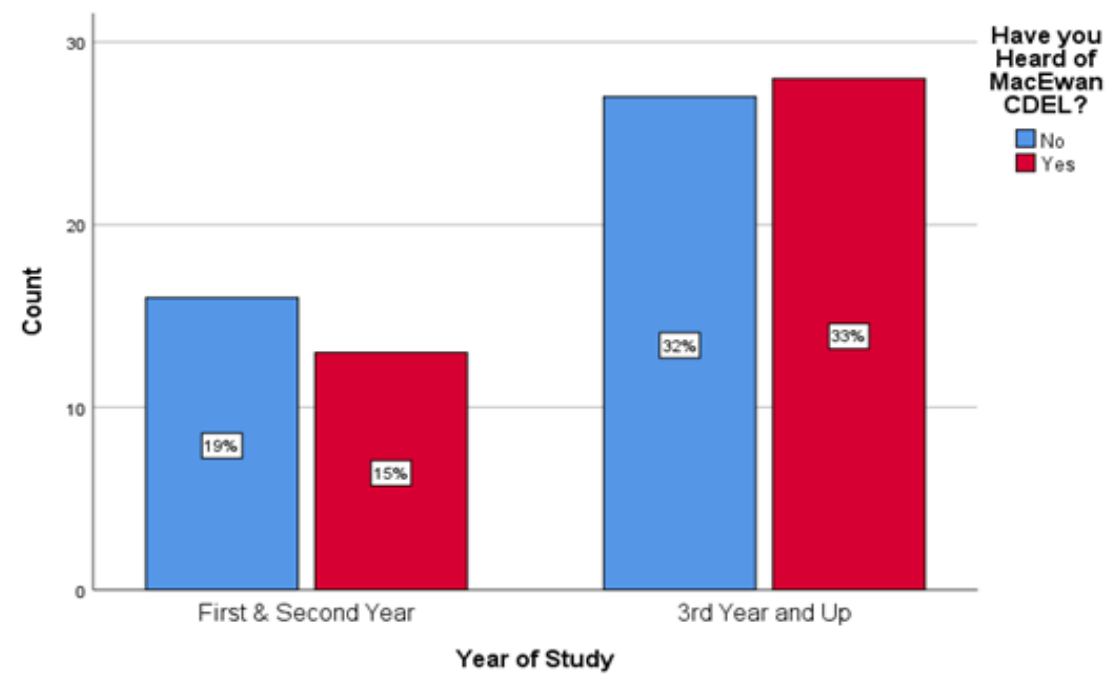

Question 2: What sources of social media would be most beneficial in reaching the target market?

For the first question, we conducted an ANOVA test to find the relationship between a respondent's preference of social media platform and whether or not they have heard of the service. The respondents were asked to rank each social media platform by 'Least Used', 'Hardly Used', 'Somewhat Used' and 'Most Used'; the respondents were also asked if they had or had not heard of CDEL. The main findings support those who are aware of CDEL use Linkedln more than those who are not aware of CDEL. However, those who are not aware of CDEL use Instagram more than those who are aware of CDEL. 


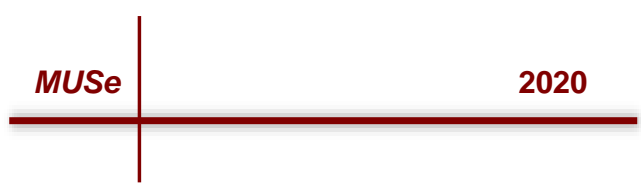

Table 4: Correlation Between Usage of Social Media Platform and Knowledge Of CDEL

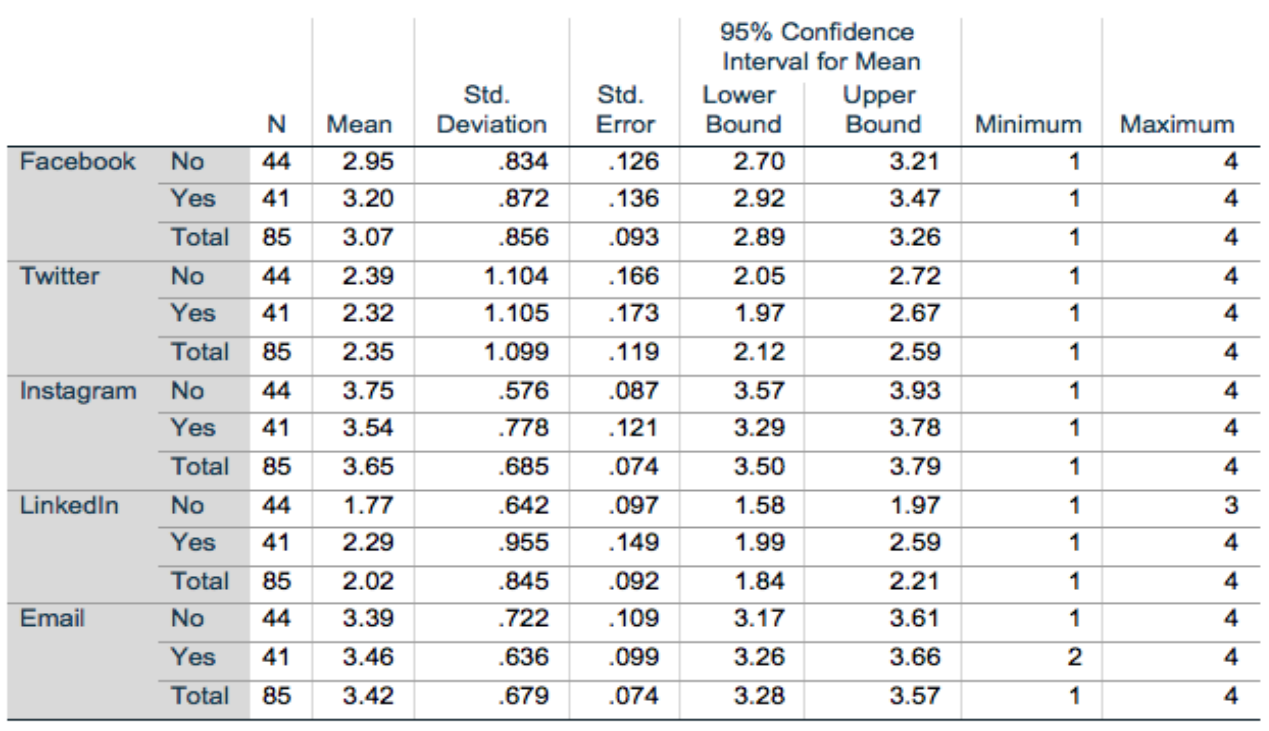

Table 5: ANOVA of Correlation Between Usage of Social Media Platform and Knowledge Of CDEL

\begin{tabular}{|c|c|c|c|c|c|c|}
\hline ANOVA & & Sum of Squares & $d f$ & $\begin{array}{l}\text { Moan } \\
\text { Square }\end{array}$ & $\mathbf{F}$ & Sig. \\
\hline \multirow[t]{3}{*}{ Facobook } & Betwoen Groups & 1.228 & 1 & $1.22 \mathrm{~B}$ & 1.689 & .197 \\
\hline & Within Groups & 60.348 & 83 & .727 & & \\
\hline & Total & 61.576 & 84 & & & \\
\hline \multirow[t]{3}{*}{ Twitter } & Betwoen Groups & .102 & 1 & .102 & .083 & .773 \\
\hline & Within Groups & 101.310 & 83 & 1.221 & & \\
\hline & Total & 101.412 & 84 & & & \\
\hline \multirow[t]{3}{*}{ Instagram } & Between Groups & .967 & 1 & .967 & 2.087 & .152 \\
\hline & Within Groups & 38.445 & 83 & .463 & & \\
\hline & Total & 39.412 & 84 & & & \\
\hline \multirow[t]{3}{*}{ Linkodln } & Betwoen Groups & 5.738 & 1 & 5.738 & 8.784 & .004 \\
\hline & Within Groups & 54.215 & 83 & .653 & & \\
\hline & Total & 59.953 & $B 4$ & & & \\
\hline \multirow[t]{3}{*}{ Email } & Betwoen Groups & .126 & 1 & .126 & .271 & .604 \\
\hline & Within Groups & 38.627 & 83 & .465 & & \\
\hline & Total & 38.753 & 84 & & & \\
\hline
\end{tabular}




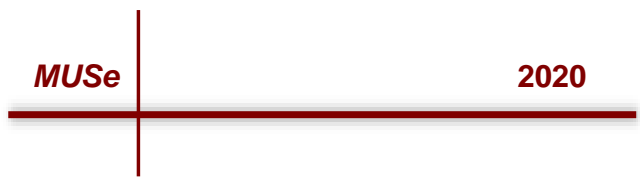

Graph 3 : Mean Usage of Social Media

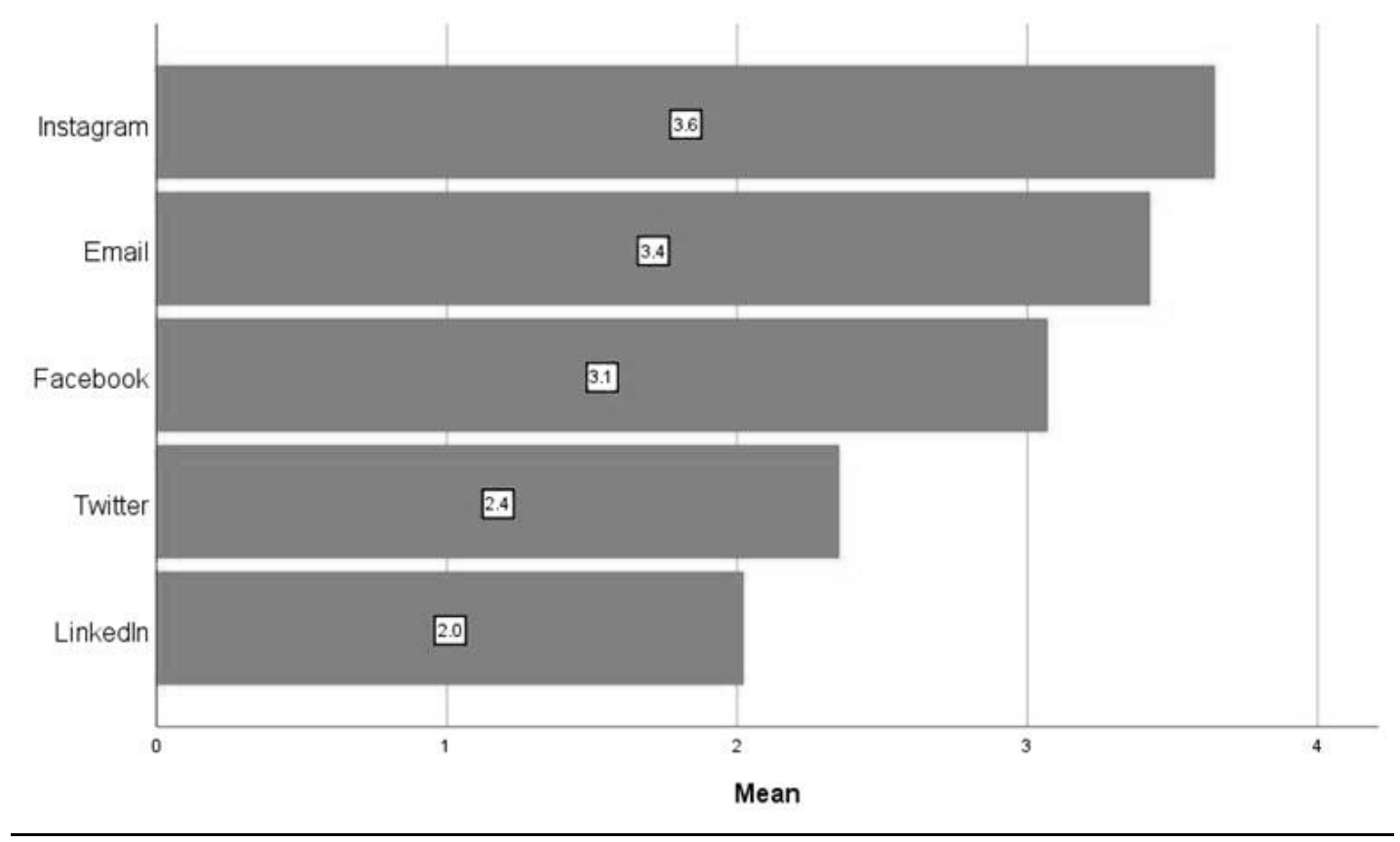

Question 3: Is there a correlation between the year students start looking for a job and if they have heard of MacEwan Career Development and Experiential Learning Centre?

For the third question, we use a crosstabulation in order to gain insight into how the two variables "When are you most likely to start looking for a job" and "Have you Heard of CDEL" correlate. Our team performed a Cross tabulation as well as a Chi- Square test in order to accept or reject our hypothesis. These variables show a high $p$-value which causes our results to reject the hypothesis that the variables are related. If we were to gather a higher amount of responses, we believe that our results would be significantly different. However, a high P-value in this correlation shows that students from all years are consistently job searching, and CDEL should target all years, not specifically 'Third and Up'. 


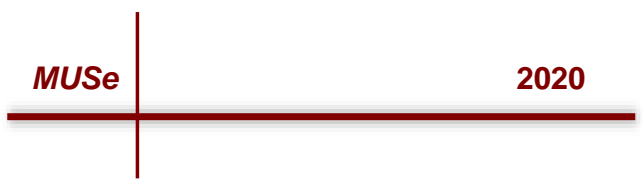

Table 6: Year Students Search or a Job* Heard of MacEwan CDEL

\begin{tabular}{|c|c|c|c|c|c|}
\hline & & & \multicolumn{2}{|c|}{ Have you Heard of CDEL? } & \multirow[b]{2}{*}{ Total } \\
\hline & & & No & Yes & \\
\hline \multirow{12}{*}{$\begin{array}{l}\text { When are you } \\
\text { most likely to } \\
\text { start looking for } \\
\text { a job? }\end{array}$} & First-Third Year & Count & 4 & 7 & 11 \\
\hline & & Expected Count & 5.6 & 5.4 & 11.0 \\
\hline & & $\begin{array}{l}\% \text { within When are you } \\
\text { most likely to start looking } \\
\text { for a job? }\end{array}$ & $36.4 \%$ & $63.6 \%$ & $100.0 \%$ \\
\hline & & $\begin{array}{l}\% \text { within Have you Heard } \\
\text { of CDEL? }\end{array}$ & $9.3 \%$ & $17.1 \%$ & $13.1 \%$ \\
\hline & & $\%$ of Total & $4.8 \%$ & $8.3 \%$ & $13.1 \%$ \\
\hline & Third-Fifth Year & Count & 21 & 16 & 37 \\
\hline & & Expected Count & 18.9 & 18.1 & 37.0 \\
\hline & & $\begin{array}{l}\% \text { within When are you } \\
\text { most likely to start looking } \\
\text { for a job? }\end{array}$ & $56.8 \%$ & $43.2 \%$ & $100.0 \%$ \\
\hline & & $\begin{array}{l}\% \text { within Have you heard } \\
\text { of CDEL? }\end{array}$ & $48.8 \%$ & $39.0 \%$ & $44.0 \%$ \\
\hline & & $\%$ of Total & $25.0 \%$ & $19.0 \%$ & $44.0 \%$ \\
\hline & Fifth Year and Up & Count & 18 & 18 & 36 \\
\hline & & Expected Count & 18.4 & 17.6 & 36.0 \\
\hline
\end{tabular}




\begin{tabular}{|c|c|c|c|c|}
\hline & & MUSe & \multicolumn{2}{|r|}{2020} \\
\hline & $\begin{array}{l}\% \text { within When are you } \\
\text { most likely to start looking } \\
\text { for a job? }\end{array}$ & $50.0 \%$ & $50.0 \%$ & $100.0 \%$ \\
\hline & $\begin{array}{l}\% \text { within Have you heard } \\
\text { of CDEL? }\end{array}$ & $41.9 \%$ & $43.9 \%$ & $42.9 \%$ \\
\hline & $\%$ of Total & $21.4 \%$ & $21.4 \%$ & $42.9 \%$ \\
\hline \multirow[t]{5}{*}{ Total } & Count & 43 & 41 & 84 \\
\hline & Expected Count & 43.0 & 41.0 & 84.0 \\
\hline & $\begin{array}{l}\% \text { within When are you } \\
\text { most likely to start looking } \\
\text { for a job? }\end{array}$ & $51.2 \%$ & $48.8 \%$ & $100.0 \%$ \\
\hline & $\begin{array}{l}\% \text { within Have you heard } \\
\text { of CDEL? }\end{array}$ & $100.0 \%$ & $100.0 \%$ & $100.0 \%$ \\
\hline & $\%$ of Total & $51.2 \%$ & $48.8 \%$ & $100.0 \%$ \\
\hline
\end{tabular}

Table 6b : Chi- Square Test : Have you Heard of CDEL * When Are You Most Likely to Start Looking for a Job

Chi-Square Tests

\begin{tabular}{|c|c|c|c|}
\hline & Value & df & $\begin{array}{l}\text { Asymptotic } \\
\text { Significance (2- } \\
\text { sided) }\end{array}$ \\
\hline Pearson Chi-Square & $1.447^{\mathrm{a}}$ & 2 & .485 \\
\hline Likelihood Ratio & 1.459 & 2 & .482 \\
\hline
\end{tabular}




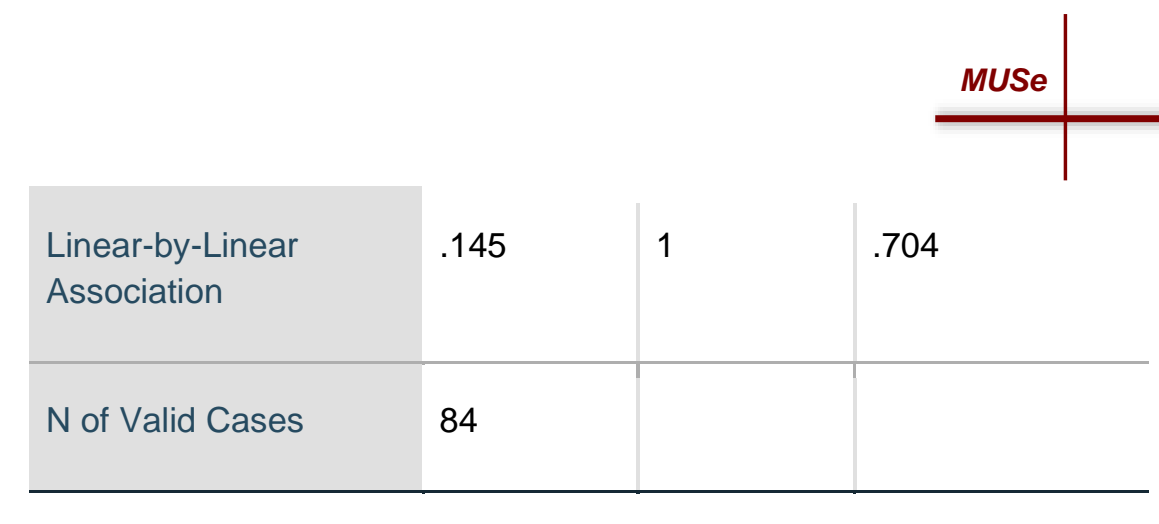

a. 0 cells $(0.0 \%)$ have expected count less than 5 . The minimum expected count is 5.37 .

$P$ value $>0.05$

Graph 4: Have You Heard Of CDEL * When Are You Most Likely to Start Looking for a Job

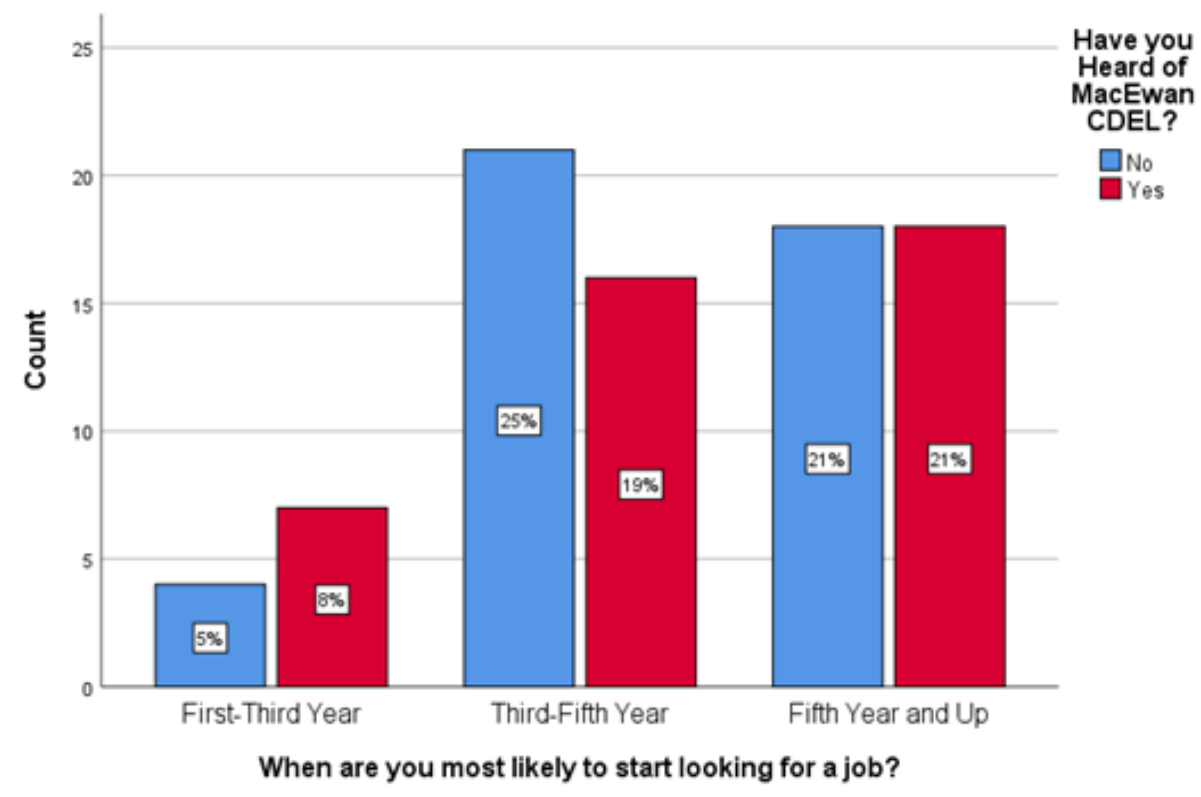

Question 5: What is the defining variable preventing MacEwan students utilizing CDEL?

To gauge how each student is prevented from utilizing the services, we performed a crosstabulation analysis followed by a Chi-squared test. The results show that the bulk of respondents are unaware of the services. By using this data and conducting a Chi-Square that resulted in a Pearson Chi- Square value of 0.002 and using an Alpha of 0.05 , we reject the null hypothesis and can conclude that these two variables are somewhat related. With this fact stated however, a large portion of the total population is unaware of the services, while some of the population does not find it valuable. When developing future plans for expansion, CDEL should keep this data that shows students are unaware of the services in mind. 


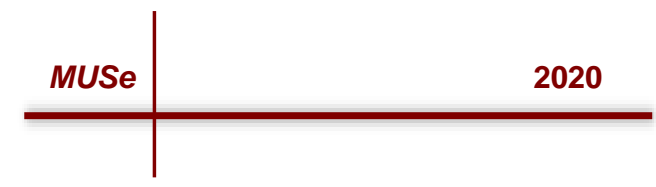

Table 7: Cross Tabulation of The Use of MacEwan Works and Reason for Not Using CDEL Services

\begin{tabular}{|c|c|c|c|c|c|}
\hline & & & \multicolumn{2}{|c|}{$\begin{array}{c}\text { Used MacEwan } \\
\text { Works }\end{array}$} & \multirow[b]{2}{*}{ Total } \\
\hline & & & No & yes & \\
\hline \multirow[t]{4}{*}{ Prevent } & \multirow[t]{2}{*}{ Not Valuable } & Count & 17 & 17 & 34 \\
\hline & & Expected Count & 23.5 & 10.5 & 34.0 \\
\hline & \multirow[t]{2}{*}{ Unaware of service } & Count & 39 & 8 & 47 \\
\hline & & Expected Count & 32.5 & 14.5 & 47.0 \\
\hline \multirow[t]{2}{*}{ Total } & & Count & 56 & 25 & 81 \\
\hline & & Expected Count & 56.0 & 25.0 & 81.0 \\
\hline
\end{tabular}

Table 7b : Chi-Square Tests

Chi-Square Tests

\begin{tabular}{|c|c|c|c|c|c|}
\hline & Value & df & $\begin{array}{c}\text { Asymptotic } \\
\text { Significance } \\
\text { (2-sided) }\end{array}$ & $\begin{array}{l}\text { Exact Sig. } \\
\text { (2-sided) }\end{array}$ & $\begin{array}{l}\text { Exact Sig. } \\
\text { (1-sided) }\end{array}$ \\
\hline Pearson Chi-Square & $10.055^{\mathrm{a}}$ & 1 & .002 & & \\
\hline Continuity Correction $^{b}$ & 8.569 & 1 & .003 & & \\
\hline Likelihood Ratio & 10.099 & 1 & .001 & & \\
\hline Fisher's Exact Test & & & & .003 & .002 \\
\hline $\begin{array}{l}\text { Linear-by-Linear } \\
\text { Association }\end{array}$ & 9.931 & 1 & .002 & & \\
\hline $\mathrm{N}$ of Valid Cases & 81 & & & & \\
\hline
\end{tabular}

a. 0 cells $(0.0 \%)$ have expected count less than 5 . The minimum expected count is 10.49 .

b. Computed only for a $2 \times 2$ table

$P$ value $<0.05$ 


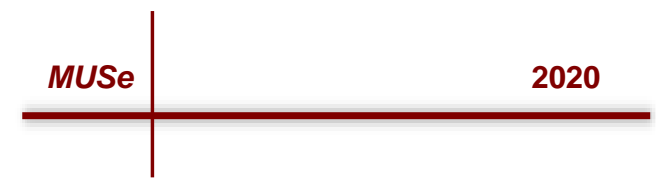

Graph 5: The Use of MacEwan Works and Reason for Not Using CDEL Services

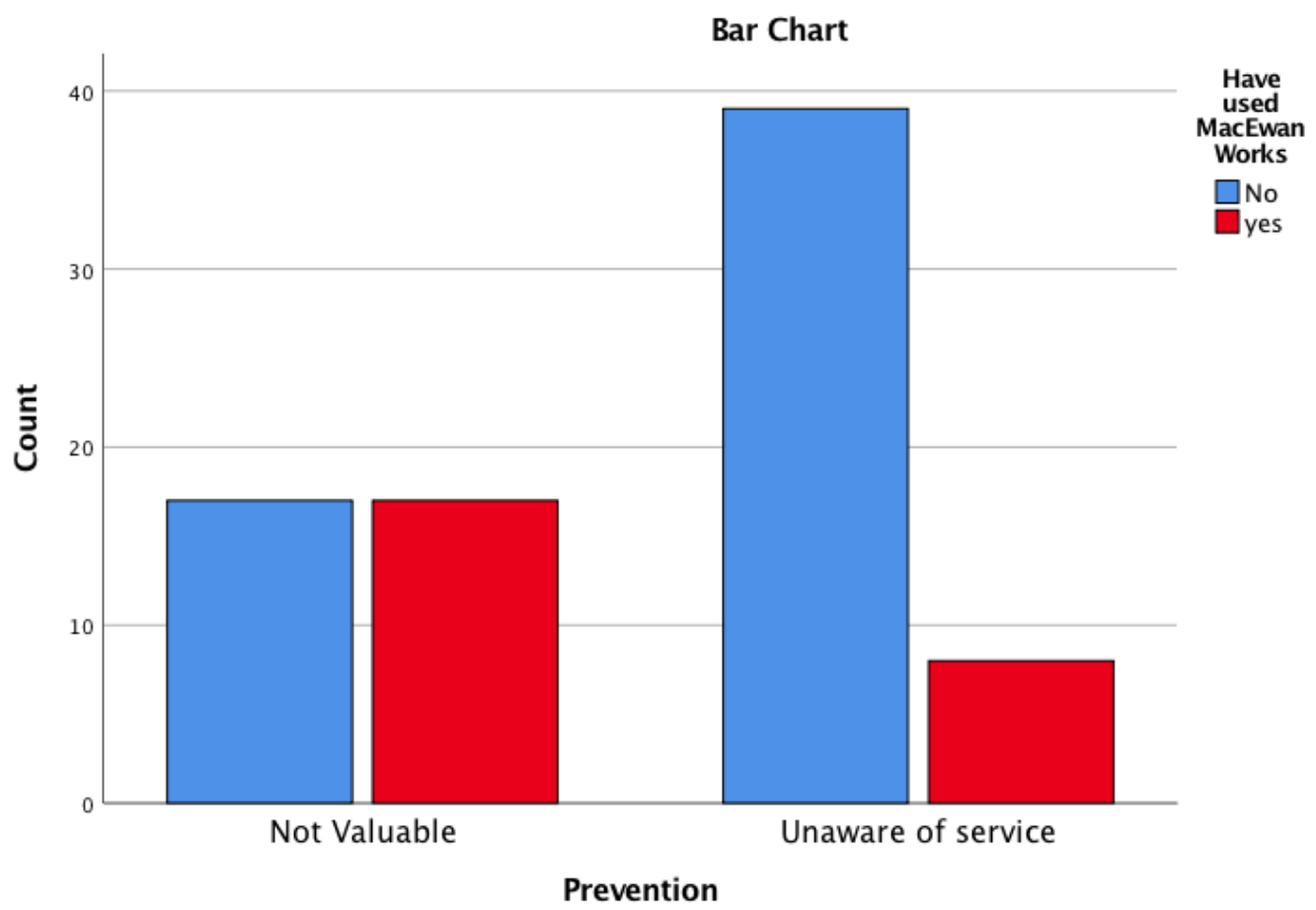

\section{Conclusions and Recommendations}

CDEL requested that we determine how to increase usage and knowledge of the service with emphasis on what physical and digital tactics would be most noticeable and informative. We began our research by developing a series of questions in relation to the marketing problem that CDEL is facing. Our team proceeded by interviewing four MacEwan students from different years of study, genders, and ages. An online survey was conducted, reaching 85 MacEwan students to further the research data.

After conducting thorough research and analyzing the survey data through univariate and bivariate analysis, our team successfully developed a targeted demographic of individuals for those who would best engage and find use for the CDEL services, and also their preferences of platforms for transfer of information. Of the five research questions we chose to apply our collected data, we formulated the following recommendations.

\section{Target students in all years of study:}

CDEL's target market is quite obviously composed of university students. After conducting the research and using bivariate analysis, our team found no significant relationship between year of study and having knowledge of CDEL. For this reason, our team suggests that CDEL should not focus on one year of study more than others but rather, try to balance marketing means amongst all years of study equally.

Another significant relationship our team found amongst all students was a lack of variance of focus on job search. From these findings we could not differentiate those who are 


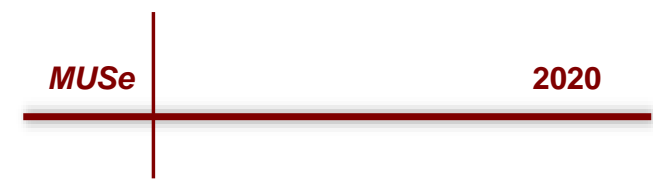

more enthusiastic about job search by year of study. We recommend that CDEL provide workshops specific to first-second year and third-fourth year students, diversifying the content according to CDEL's guidelines of necessities within each year of study. Having workshops for those first-year students will also create longer lasting relationships with students early on. This should therefore enhance the flow of students using the service, along with word of mouth about service. Applying these workshops to four years of study will allow all students equal opportunity to access help with job searches and career related advice.

\section{Ideal Method for Transfer of Information}

The comparison of social media platform usage amongst all respondents resulted in Instagram being the most popular and Email, Facebook, Twitter and Linkedln being less and less significant consecutively. The relationship between usage of media platforms to the awareness of CDEL (by bivariate analysis) suggests those who use Linkedln more often are more aware of CDEL than those who use Linkedln less often; findings also concluded that the majority of those who have not heard of CDEL use Instagram the most. We recommend CDEL use Instagram to convert unaware students and put emphasis on Linkedln to continue to increase awareness levels.

The second relationship we found by univariate analysis was the preference for transfer of information about CDEL through Blackboard, email, posters, social media and classroom visits. Students prefer to hear directly from CDEL through Blackboard first and email second, and least from posters and in class visits. Students significantly chose blackboard for easy access to MacEwan Works and CDEL information. We recommend continuing to advocate for a link to MacEwan Works on Blackboard. We suggest that CDEL delegate an individual to the preparation of weekly updates and to be persistent in getting faculty newsletters/email newsletters to relay this information. Students emphasize how often they check their email so we believe this would be the best way to transfer information. With each service a student uses in the CDEL office, we suggest asking permission to use email to send a weekly newsletter and including the option to 'recommend a friend' with a certain incentive to generate interest.

\section{Implementation of online interaction}

Students are much more in touch with online content than physical engagement. Our research involved asking participants if they preferred seeing posters, services and ambassadors promoting within the halls. This was quickly removed from our data sets as the responses were not significant. Students were enthusiastic about social platforms. To engage the students more in the services CDEL has to offer, we suggest developing a simple application 'checklist' for mobile devices that can be accessed by links from other social media pages. Creating broad checklists that relate to all faculties would be a good starting point, then further developing indepth lists for specific faculties and majors. This can be used in direct reference to the workshops. Also, CDEL should include information and content from MacEwan Works website on the app and links to other sources of information, such as videos on interview guidelines. Developing an application that provides students with a visual checklist that is easily accessible at the touch of their fingertips may help CDEL provide students with the information needed to succeed. 


\section{Limitations}

During our data collection, we acknowledged the fact that there are always limitations with research objectives. For the purpose of our research, we identified the following limitations:

1. The sample size has been limited to 85 people. Although the responses we received were valuable for the analysis and application of our research question, our team would have liked to get a mass survey to properly identify our target market on all fronts. Being that this type of service can apply to a variety of university years of study and demographics of people's needs, having a larger data collection may have shown more correlation amongst variables to affirm our hypothesis

2. Lack of previous research studies in university student engagement. Literary review is needed to identify the scope of works that have been done in the research are so far. We were able to take key points from separate studies in order to compose analytical solutions for CDEL, but with little directly related prior research it was hard to gain relatable insight with a direct research problem like ours.

3. CDEL requested how to generate more urgency with first year students. Our research found that students in the first couple years did not want to use the services as they see no need, which limits CDEL in that target demographic.

4. The amount of time that our group was allotted to collect data and target our population was a limitation as well. If there was a greater time period, we would have been able to collect additional responses that would have made our data

5. In conducting surveys and questionnaires, authenticity and accuracy is a limitation. We are unable to control whether respondents provided truthful answers, unless the questionnaire was conducted in person, however, our time limitation prevented our group from doing so. 


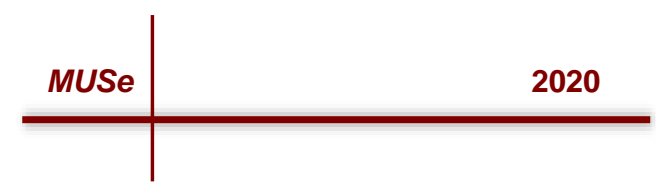

\section{References}

Baig, Sidra Tabassum Ashraf, "The Effects of a Career Development Course on Career and College Major Decision-Making in College Students" (2012). Theses, Dissertations, Professional Papers. Paper 997. Retrieved January 29, 2018, from https://scholarworks.umt.edu/cgi/viewcontent.cgi?referer=https://www.google.ca/\&httpsre dir $=1 \&$ article $=2016 \&$ context $=$ etd

Burton, K., McKenzie, EW., Damo, P. (2009). Honors Ambassadors: A Framework for Enhancing Student and Program Development. Honors in Practice, 5, p.171. Retrieved from:

http://content.ebscohost.com.ezproxy.macewan.ca/ContentServer.asp?EbscoContent=d GJyMNLr40Seqa44yNfsOLCmr1Cep7RSsK\%2B4SbOWxWXS\&ContentCustomer=dGJ yMPGgt0uyrLVRuePfgeyx43zx1\%2B6B\&T=P\&P=AN\&S=R\&D=0fs\&K=508033968

Butcher, J. (2009). Off-campus learning and employability in undergraduate design: the Sorrell Young Design Project as an innovative partnership. Art, Design \& Communication in Higher Education, 7(3), 171-184. https://doi.org/10.1386/adch.7.3.171 1

Cojocariu, V. and Puiu, M. (2014). Career - Counselling Practices for University Students. Procedia - Social and Behavioral Sciences,149, pp.222-227. https://doi.org/10.1016/i.sbspro.2014.08.221

Cole, H., DeNardin, T., \& Clow, K. (2017). Small Service Businesses: Advertising Attitudes and The Use of Digital and Social Media Marketing. Services Marketing Quarterly, 38(4), 203-212. https://doi.org/10.1080/15332969.2017.1394026

Crisan, C., Pavelea, A. and Ghimbulut, O. (2015). A Need Assessment on Students' Career Guidance. Procedia - Social and Behavioral Sciences, 180, pp.1022-1029.

Dias, L., \& Phillip, S. (2016). The Effects of a University Career Development Course of Career Decision-Making Self-Efficacy. Academy of Business Research Journal. Vol. 4, p7-17. 11p. Retrieved from: http://content.ebscohost.com.ezproxy.macewan.ca/ContentServer.asp?EbscoContent=d GJyMNXb4kSeqa84yNfsOLCmr1Cep7ZSsqi4TbOWxWXS\&ContentCustomer=dGJyMP Gqt0uyrLVRuePfgeyx43zx1\%2B6B\&T=P\&P=AN\&S=R\&D=bth\&K=122256219

Drier Jr., H. \& Norton, R. (1975). Maximizing the utilization of Community Resources in Career Education. Journal of Career Education, 1(4), 2. Retrieved from: http://content.ebscohost.com.ezproxy.macewan.ca/ContentServer.asp?EbscoContent=d GJyMNLr40Seqa44yNfsOLCmr1Cep7VSs6y4TLOWxWXS\&ContentCustomer=dGJyMP GqtOuyrLVRuePfgeyx43zx1\%2B6B\&T=P\&P=AN\&S=R\&D=bth\&K=18661354

Fiddler, M. B., Fine, B. A., \& Baker, D. L. (1996). A case-based approach to the development of practice-based competencies for accreditation of and training in graduate programs in 


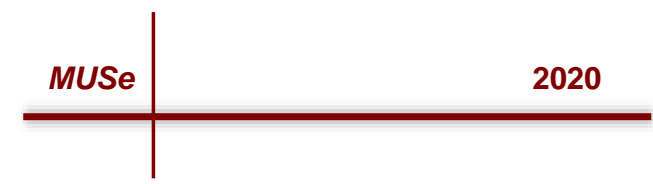

genetic counseling. Journal of Genetic Counseling, 5(3), 105-112.

https://doi.org/10.1007/bf01408655.

Fouad, N., Cotter, E. W., \& Kantemneni, N. (2009). The Effectiveness of a Career Decision Making Course . Journal of Career Assessment, 17(3), 338-347. Retrieved January 28, 2018, from http://journals.sagepub.com.ezproxy.macewan.ca/doi/pdf/10.1177/1069072708330678

Griffin, K., Cangelosi, J., McMurtrey, M., \& Lyons, L. (2017). What Skills Do Students Think are Important for Jobs. Competition Forum, 15(2), 303-309. Retrieved from SPORTDiscus Database. (Ascension No. 125981015)

Islam, M., \& Habiba, U. (July 2015). Use of Social Media in Marketing of Library and Information Services in Bangladesh. DESIDOC Journal of Library \& Information Technology, 35(4), 299-303. Retrieved from: https://library.macewan.ca/library-search/detailedview/lih/108779093?query=Marketing+in+Social+Media

Jameson, H. P., \& Goshit, S. (2017). Building Campus Communities Inclusive of International Students: A Framework for Program Development. New Directions for Student Services, 2017(158), 73-85. https://doi.org/10.1002/ss.20221

King, P. (2014). Enriching the Student Learning Experience: Linking Student Development and Organizational Perspectives. About Campus, 19 (1), p.8. Retrieved from: http://content.ebscohost.com.ezproxy.macewan.ca/ContentServer.asp?EbscoContent=d GJyMNLr40Seqa44yNfsOLCmr1Cep7RSsKe4SLKWxWXS\&ContentCustomer=dGJyMP Gqt0uyrLVRuePfgeyx43zx1\%2B6B\&T=P\&P=AN\&S=R\&D=ehh\&K=95425596

Little, S. (2016). Promoting a Collective Conscience: Designing a Resilient Staff-Student Partnership Model for Educational Development. International Journal for Academic Development, 21(4), p.275. Retrieved from: http://www.tandfonline.com.ezproxy.macewan.ca/doi/pdf/10.1080/1360144X.2016.12095 $\underline{05}$

Marks, T., \& Le, A. (Winter 2017). Increasing Article Findability Online: The Four Cs of Search Engine Optimization. Law Library Journal, 109(1), 83-99. Retrieved from https://library.macewan.ca/library-search/detailedview/edswss/000397202800004?query=search+engine+optimization

McFall, Jr., D. \& Zucca, L. (2008). Recruiting (and Retaining). Journal of Accountancy, 205(4), 63. Retrieved from: http://content.ebscohost.com.ezproxy.macewan.ca/ContentServer.asp?EbscoContent=d GJyMNLr40Seqa44yNfsOLCmr1Cep7NSs6e4TK6WxWXS\&ContentCustomer=dGJyMP Gqt0uyrLVRuePfgeyx43zx1\%2B6B\&T=P\&P=AN\&S=R\&D=bth\&K=31934379

Minton, E., Lee, C., Orth, U., Kim, C., \& Kahle, L. (Winter 2012). Sustainable Marketing and Social Media. Journal Advertising, 41(4), 69-84. https://doi.org/10.2753/JOA0091$\underline{3367410405}$ 


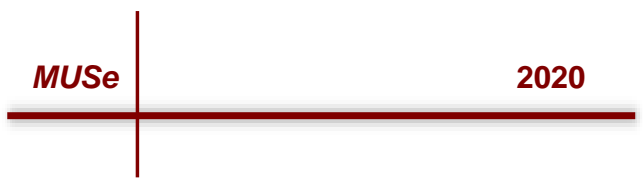

Ng, E. S., \& Burke, R. J. (2006). The next generation at work - business students views, values and job search strategy. Education Training, 48(7), 478-492. Retrieved from:

http://www.emeraldinsight.com.ezproxy.macewan.ca/doi/pdfplus/10.1108/004009106107 05872doi:10.1108/00400910610705872

Oliver, L. W., \& Spokane, A. R. (1988). Career-intervention outcome: What contributes to client gain? Journal of Counseling Psychology, 35(4), 447-462. https://doi.org/10.1037//0022$\underline{0167.35 .4 .447}$

Paradnike, K. and Bandzeviciciene, R. (2016). CAREER CONSTRUCTION IN ACADEMIC SETTING: LINK BETWEEN CAREER ADAPTABILITY AND STUDY ENGAGEMENT. International Journal of Psychology: a Biopsychosocial Approach, (18), 71-88.

Puchkoff, S. and Lewin, P. (1987). Student responsiveness to specialized college services: Contribution of personality variables and perceptions of services. Journal of Counseling Pyschology, 34(3), 330-332.

Zhang, S., \& Cabage, N. (2017). Search Engine Optimization: Comparison of Link Building and Social Sharing. Journal of Computer Information Systems, 57(2), 148-159. https://doi.org/10.1080/08874417.2016.1183447

Zucca, L. J., \& Mcfall, D. W. (2008). Recruiting (and Retaining) the Next Generation Accountant: One University's Experience. Journal of Accountancy, 205(4), 60-66. Retrieved February 20, 2018, from

http://content.ebscohost.com.ezproxy.macewan.ca/ContentServer.asp?EbscoContent=d GJyMNLr40SeqLU4xNvgOLCmr1Cep7dSsay4SraWxWXS\&ContentCustomer=dGJyMP Gqt0uyrLVRuePfgeyx43zx1\%2B6B\&T=P\&P=AN\&S=R\&D=ofs\&K=510784050 


\section{Appendix}

Appendix A: Questionnaire

CAREER DEVELOPMENT AND EXPERIENTIAL LEARNING QUESTIONNAIRE

1. What is your gender?

$\square$ Female $\quad \square$ Male

2. What is your age?

$\square 18$ and Under $\square 19-21 \quad \square 22$ and Up

3. What occupation do you currently hold? (Check all that apply)

$\square$ Full-Time Student $\quad \square$ Part-Time Student $\quad \square$ Full-Time Employee

Part-Time Employee $\quad \square$ Unemployed

4. Which year of study are you in?
$\square$ First Year
Second Year
Third Year
$\square$ Fourth Year
$\square$ Fifth Year
$\square$ Sixth year or up

5. Have you heard of MacEwan's Career and Experiential Learning Service?

$\square$ Yes $\quad \square$ No

6. Have you used MacEwan's Career Development and Experiential Learning Service?

$\square$ Yes $\square$ No

7. If yes, which services have you made use of? (Check all that apply)

$\square$ Linkedln Building $\quad \square$ Resume and Cover Letter Building $\square$ Mock Interviews 
\begin{tabular}{r|r} 
MUSe & 2020 \\
\hline &
\end{tabular}

$\square$ My Career Journey $\quad \square$ Job Posting $\quad \square$ Career Related Resources $\quad \square$ Other

$\square$ None

8. If you have not used the service, which services would you like to make use of? (Check all that apply)

$\square$ Linkedln Building $\quad \square$ Resume and Cover Letter Building $\square$ Mock Interviews $\square$ My Career Journey $\square$ Job Posting $\quad \square$ Career Related Resources $\quad \square$ Other

9. Would it be useful if the above career resources were available on CDEL's website?

$\square$ Yes $\quad \square$ No

10. What means of communication would you find most useful to find out more about the services?

$\square$ Posters

$\square$ In-Class visits $\square$ Social Media

E-mail

$\square$ Blackboard $\square$ Myportal

11. Rank the following social media platforms in order of preference. Assign 1 to the platform you use the most, assign 2 to the second most used platform. Continue with this procedure until you have ranked all of the social media platforms in order of preference. No two platforms should receive the same rank number.

Facebook

Twitter

Instagram

Linkedln

12. What prevents you from using our services?

$\square$ Have no time $\square$ Don't see a need for it $\quad \square$ Unaware of service

Difficulty booking $\square$ Difficulty finding the office 
13. At what point are you most likely to start looking for a job?

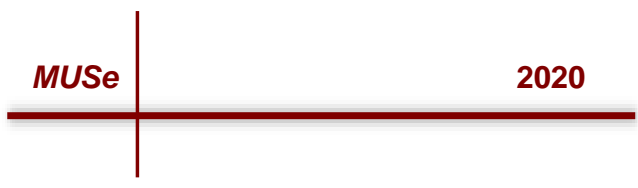
$\square$ First-Second Year $\square$ Second-Third Year
Fourth-Fifth Year $\square$ After Graduation

14. Have you accessed the MacEwan Works website?

$\square$ Yes $\square$ No

15. After completing this survey how likely are you to access CDEL services?

$\square$ Unlikely $\square$ Somewhat likely $\square$ Likely $\square$ Very likely

\section{A. In-Depth Interviews Participant Profiles}

Table 1. In-Depth Interview \#1

\begin{tabular}{|l|l|}
\hline Individual Interviewed: & Ashley \\
\hline Year at MacEwan: & 3rd \\
\hline $\begin{array}{l}\text { Program of Study and } \\
\text { Major/Minor: }\end{array}$ & $\begin{array}{l}\text { Bachelor of Commerce, } \\
\text { Undeclared Major }\end{array}$ \\
\hline Interviewer: & Amanda \\
\hline Date: & February 23, 2018 \\
\hline
\end{tabular}

Table 2. In-Depth Interview \#2

\begin{tabular}{|l|l|}
\hline Individual Interviewed: & Sabrina Somani \\
\hline Year at MacEwan: & First year \\
\hline
\end{tabular}




\begin{tabular}{|l|l|}
\hline $\begin{array}{l}\text { Program of Study and } \\
\text { Major/Minor: }\end{array}$ & $\begin{array}{l}\text { Arts, transferring to } \\
\text { Business to major in } \\
\text { Accounting }\end{array}$ \\
\hline Interviewer: & Nicole \\
\hline Date: & February 16, 2018 \\
\hline
\end{tabular}

Table 3. In-Depth Interview \#3

\begin{tabular}{|l|l|}
\hline Individual Interviewed: & Angela \\
\hline Year at MacEwan: & Second Year \\
\hline $\begin{array}{l}\text { Program of Study and } \\
\text { Major/Minor: }\end{array}$ & $\begin{array}{l}\text { Bachelor of Commerce, } \\
\text { Potential Accounting } \\
\text { Major }\end{array}$ \\
\hline Interviewer: & Sarah \\
\hline Date: & Feb 14, 2018 \\
\hline
\end{tabular}

Table 4. In-Depth Interview \#4

\begin{tabular}{|l|l|}
\hline Individual Interviewed: & Miguel \\
\hline Year at MacEwan: & Third \\
\hline $\begin{array}{l}\text { Program of Study and } \\
\text { Major/Minor: }\end{array}$ & $\begin{array}{l}\text { Bachelor of Commerce } \\
\text { Accounting Major }\end{array}$ \\
\hline Interviewer: & Kyra Sklar \\
\hline
\end{tabular}




\begin{tabular}{l|l}
\hline Date: & Feb 25
\end{tabular}

\section{B. Interview with Decision Makers}

Table 1. Interview Information

\begin{tabular}{|l|l|}
\hline Organization/ Service Name & Career Development and Exponential Learning \\
\hline Location & $\begin{array}{l}10505107 \text { Street Northwest, MacEwan University, } \\
\text { Edmonton, AB T5H 2Y5 }\end{array}$ \\
\hline Individual Interviewed & Gillian Kemp, Dorothy Ritz \\
\hline Position & Exponential Learning Facilitator \\
\hline Date & January 26, 2018 \\
\hline Time & $11: 30$ am \\
\hline
\end{tabular}

Table 2. Expectations and Additional Questions from CDEL

\begin{tabular}{|l|l|}
\hline Expectations & - Focus on MacEwan students \\
- & Constructive feedback from both parties \\
- Analyze opinions on career planning in university & Incorporate measurements between student usage and \\
- & experience \\
& Goals for Career Development and Exponential Learning \\
so far- survey if they have accessed services, how urgent \\
is your job search, if already started a job search by now \\
does this develop more urgency \\
Discuss the use of visual maps, themes for engaging \\
students and other activities that may increase the use of \\
the service
\end{tabular}




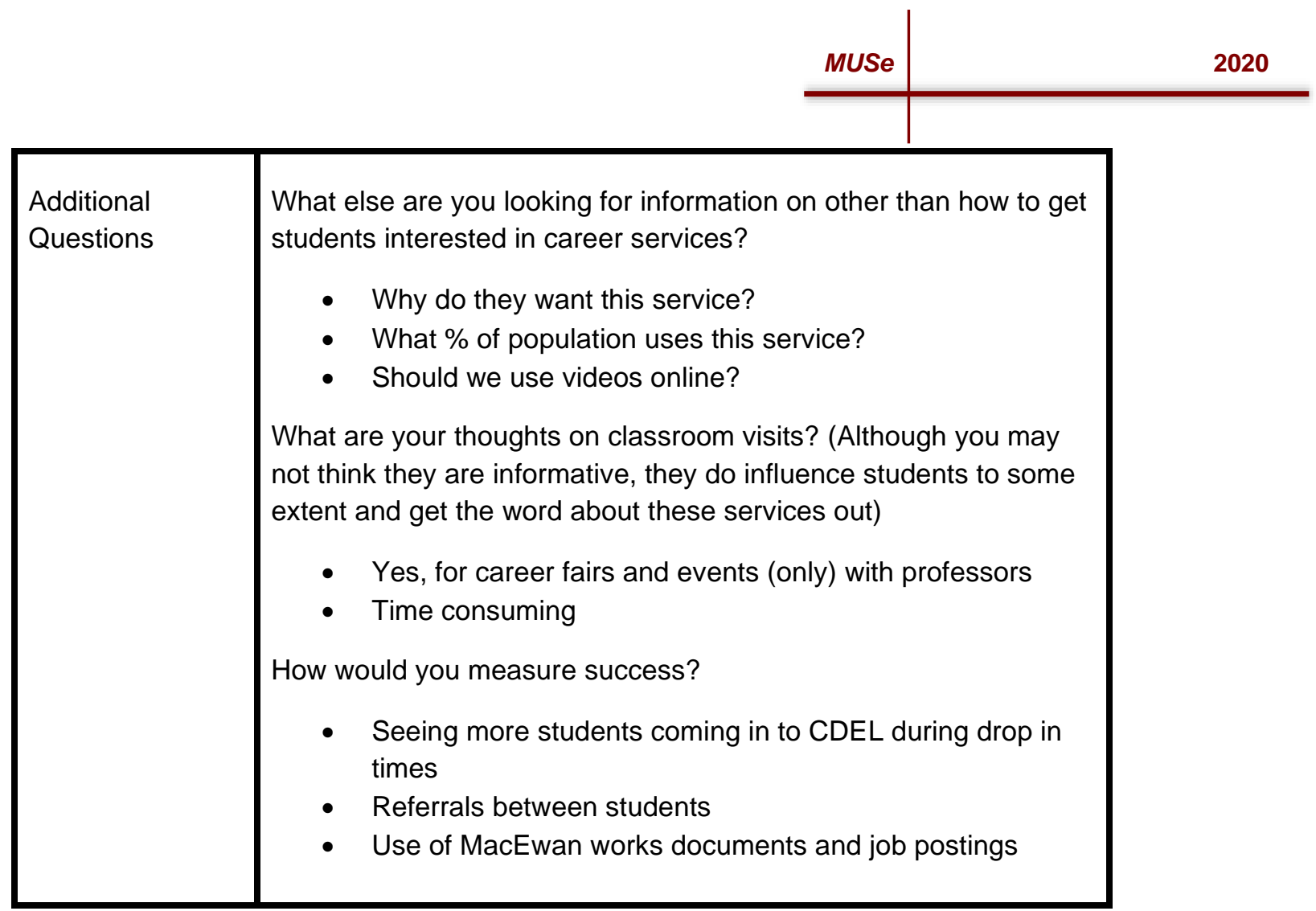

\section{Appendix B. Discussion Guide}

\section{Introduction and Justification}

Who we are: We are a group of students conducting research on the behalf of MacEwan Career Development and Experiential Learning Services in accordance with Marketing Research 312 facilitated by Fernando Angulo Ruiz.

What Is Our Purpose: To gather relevant data to help MacEwan Career Development and Experiential Learning Services make an educated decision towards marketing strategies.

What is Our Objective: The focus of this study is to discover how MacEwan Career Development and Experiential Learning Services can market to students of MacEwan and express the importance and value of their services.

Research Problem: How can MacEwan Career Development and Experiential Learning Services engage with MacEwan students and further understand their wants and needs.

Validation of Consent 
In-Depth Interview Questions:

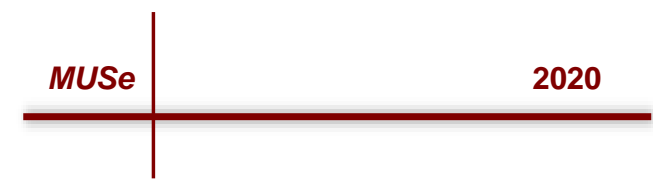

1. In what ways have you planned out your future after graduating university?

2. Are you aware of career development and exponential learning services at MacEwan (it's a career service)?

3. Have you USED or NOT USED MacEwan career services (CDEL)? Do you feel prepared to enter the job force after graduation?

4. What means of communication would you find most useful to find out more about these types of services?

5. If notified by school promotion about the urgency of career planning, would this make you more likely to contact CDEL? Why?

6. Have you ever been notified of the services available to students in the CDEL? If yes, how have you heard about them? If yes, list some of the services available to students.

7. What age range are you more likely to discuss career dreams, goals, ask for advice too? Someone that is a year or two older than you, someone recently graduated, or someone with experience in career counselling?

8. At what point are you most inclined to start looking for a job or coop program?

9. If given student ambassadors as mentors that have experience and training, would you be more or less likely to use the service? Explain.

10. Why did you use CDEL? Was it a positive or negative experience?

Wrap Up

Thank you for your time

- Do you have any questions?

- Would you like any further information regarding the study? 